\title{
Human Papillomavirus Burden in Different Cancers in Iran: a Systematic Assessment
}

\author{
Somayeh Jalilvand ${ }^{1}$, Zabihollah Shoja ${ }^{2}$, Rasool Hamkar ${ }^{1 *}$
}

\begin{abstract}
Certain types of human papillomaviruses (HPVs) are undoubtedly involved in genesis of human malignancies. HPV plays an etiological role in cervical cancer, but also in many vaginal, vulvar, anal and penile cancers, as well as head and neck cancers. In addition, a number of non-malignant diseases such as genital warts and recurrent respiratory papillomatosis are attributable to HPV. Moreover, HPV forms have detected in several other cancers including esophageal squamous cell carcinoma, lung, prostate, ovarian, breast, skin, colorectal and urinary tract cancers, but associations with etiology in these cases is controversial. The aim of this systematic assessment was to estimate the prevalence of HPV infection and HPV types in HPV-associated cancers, HPV-related non-malignant diseases and in cancers that may be associated with HPV in Iran. The present investiagtion covered 61 studies on a variety of cancers in Iranian populations. HPV prevalence was $77.5 \%$ and $32.4 \%$ in cervical cancer and head and neck cancers, respectively. HPV was detected in $23.1 \%, 22.2 \%, 10.4 \%, 30.9 \%, 14 \%$ and $25.2 \%$ of esophageal squamous cell, lung, prostate, urinary tract cancers, breast and skin cancers, respectively. HPV16 and 18 were the most frequent HPV types in all cancers. The findings of present study imply that current HPV vaccines for cervical cancer may decrease the burden of other cancers if they are really related to HPV.
\end{abstract}

Keywords: Human papillomaviruses - prevalence - HPV types - cancer types - Iran

Asian Pac J Cancer Prev, 15 (17), 7029-7035

\section{Introduction}

Cancer is one of the most important mortal agents in Iran. Breast cancer, with estimated the age standardized incidence rate (ASR) 18.4, is the first common cancer and cervical cancer is the eleventh frequent cancer in Iranian women. Prostate cancer, with reported ASR 11.6, is the second most prevalent in Iranian men. Stomach, colorectum, bladder, esophagus and lung cancers are common cancers in both sex $(\mathrm{ASR}=15.6,7.6,7,6.8$ and 6.4per 100,000, respectively) (IARC, 2008).

Certain types of Human papillomaviruses (HPVs) are undoubtedly involved in human malignancies. One of the most important HPV-related cancers is cervical cancer that is the third most frequently cancer in women worldwide (Jemal et al., 2011; Moscicki et al., 2012). Also, HPV plays an etiological role in many vaginal, vulvar, anal, penile, as well as head and neck cancers (Gillison et al., 2012d; Moscicki et al., 2012). In addition, a number of non-malignant diseases such as genital warts and recurrent respiratory papillomatosis are attributable to HPV, particularly HPV6 and 11 (Chelimo et al., 2013; Gillison et al., 2012c). Moreover, HPV detected in several other cancers including esophageal squamous cell carcinoma (Syrjanen, 2002b; Tornesello et al., 2009), lung
(Rezazadeh et al., 2009b; Munoz et al., 2012), prostate (Lin et al., 2011), ovarian (Rosa et al., 2013), breast (Simoes et al., 2012), skin (Iftner et al., 2003), colorectal (Burnett-Hartman et al., 2008; Lorenzon et al., 2011) and urinary tract cancers ( $\mathrm{Li}$ et al., 2011), but association of HPV to these cancers is controversial.

Infection by specific types of HPV, particularly HPV16 and 18 , is responsible for development of HPV-related cancers. It is identified that most HPV-related cancers and HPV weekly related cancers are associated to infections by high-risk types including $16,18,31,33,35,39,45,51$, 52, 56, 58, 59, 68 and 73 (Munoz et al., 2003; Cogliano et al., 2005; Munoz et al., 2006; Bouvard et al., 2009; Doorbar et al., 2012).

In the HPV-associated cancers commonly several years after the initial infection, tumors progress in the epithelia. Persistent infection with expression of some viral genes, particularly E6 and E7 is needed for development of invasive cancer. However, most HPV infections have a benign outcome because nearly half of them clear within 6 months and up to 2 years the majority of cases clear from infection, but those that persist can progress to cancer (Rodriguez et al., 2010; Moscicki et al., 2012).

The aim of this systematic review is to estimate the prevalence of HPV infection and HPV types in HPV- 
Table 1. List of Studies on HPV-related Cancers (Cervical Cancer and Head \& Neck Cancers) and Healthy Subjects in Iranian Population

\begin{tabular}{|c|c|c|c|c|c|c|c|c|}
\hline Samples & $\begin{array}{c}\text { "Province } \\
\text { (Sampling time)" }\end{array}$ & Year & $\begin{array}{l}\text { "Mean or median } \\
\text { age (y) (Range)" }\end{array}$ & No. & $\begin{array}{l}\text { "HPV pos } \\
\mathrm{N}(\%) "\end{array}$ & $\begin{array}{l}\text { "Detection method } \\
\text { (Primers)" }\end{array}$ & Typing-method & References \\
\hline \multicolumn{9}{|l|}{ Cervix } \\
\hline \multirow{17}{*}{ ICC } & Gilan & 2002 & - & 39 & $29(74.3)$ & $\mathrm{PCR}(\mathrm{GPs})^{\mathrm{a}}$ & $\mathrm{ISH}^{\mathrm{b}}$ & (Hamkar et al., 2004) \\
\hline & Golestan & 2002 & - & 43 & $31(72.1)$ & PCR (GPs) & ISH & (Hamkar et al., 2004) \\
\hline & Mazandaran & 2002 & & 42 & 33 (78.6) & PCR (GPs) & ISH \& Sequencing & (Hamkar et al., 2002) \\
\hline & Tehran & 2002 & - & 69 & $59(85.5)$ & ISH & $\operatorname{TSP}^{\mathrm{c}}(\mathrm{HPV} 16,18,33)$ & (Mortazavi et al., 2002) \\
\hline & Fars & 2003 & 49.1 & 101 & $88(87.1)$ & - & - & (Farjadian et al., 2003) \\
\hline & Tehran & 2006 & $52.5(32-73)$ & 64 & $38(59.4)$ & TSP PCR & TSP $(H P V 16,18)$ & (Maleknejad et al., 2006) \\
\hline & Tehran (2005-2006) & 2006 & 35.3 & 7 & $7(100)$ & PCR (GPs) & TSP (HPV6,11,16,18,31,33) & (Ghaffari et al., 2006) \\
\hline & $\begin{array}{l}\text { "East Azarbaijan } \\
\text { (2000-2006)" }\end{array}$ & 2007 & $51.1(29-79)$ & 74 & $47(63.5)$ & PCR (GPs) & Type specific multiplex & (Esmaeili et al., 2008) \\
\hline & $\begin{array}{l}\text { Tehran (1999-2005) } \\
\text { "West Azarbiian }\end{array}$ & 2007 & $52.16(30-75)$ & 37 & $32(86.5)$ & PCR & Hybridization & (Yarandi et al., 2007) \\
\hline & (1999-2005)" & 2007 & $51.8(31-83)$ & 18 & $10(55.5)$ & PCR & TSP (HPV16,18) & (Omrani et al., 2007) \\
\hline & Yazd & 2007 & $47.2(23-86)$ & 40 & $30(75.0)$ & PCR (GPs) & Sequencing & (Mahmoodi et al., 2007) \\
\hline & Tehran & 2008 & $46.5(25-68)$ & 70 & $34(48.6)$ & PCR Kit & Typing PCR Kit (Sacace) & (Eslami et al., 2008b) \\
\hline & Tehran (2003-2007) & 2011 & $48(28-72)$ & 87 & $72(82.7)$ & Real-time (GPs) & Sequencing & (Shahsiah et al., 2011) \\
\hline & Tehran (2002-2008) & 2011 & $51(26-84)$ & 45 & $45(100)$ & PCR (GPs) R & Reverse-line blot hybridization & (Khodakarami et al., 2012) \\
\hline & Isfahan (2007-2009) & 2011 & $52(29-73)$ & 47 & 45 (95.7) & PCR (GPs) & - & (Allameh et al., 2011) \\
\hline & Isfahan (2006-2010) & 2011 & - & 12 & $12(100)$ & PCR (GPs) & Real-time & (Heidarpour et al., 2011) \\
\hline & Mazandaran (2009-2011) & 2013 & 52.6 & 67 & $56(83.6)$ & PCR & $\begin{array}{l}\text { HPV Genotype-Eph kit } \\
\text { (AmpliSens) }\end{array}$ & (Haghshenas et al., 2013) \\
\hline \multirow[t]{9}{*}{ HSIL } & Tehran (2005-2006) & 2006 & 35.3 & 7 & $5(71.4)$ & PCR (GPs) & $\operatorname{TSP}(6,11,16,18,31,33)$ & (Ghaffari et al., 2006) \\
\hline & $\begin{array}{l}\text { "East Azarbaijan } \\
(2000-2006) "\end{array}$ & 2007 & $51.1(29-79)$ & 34 & $28(82.3)$ & PCR (GPs) & Type specific multiplex & (Esmaeili et al., 2008) \\
\hline & Tehran (1999-2005) & 2007 & $39.80(26-52)$ & 40 & $15(37.5)$ & PCR & Hybridization & (Yarandi et al., 2007) \\
\hline & $\begin{array}{l}\text { "West Azarbaijan } \\
\text { (1999-2005)" }\end{array}$ & 2007 & $51.8(31-83)$ & 1 & $0(0.0)$ & PCR & TSP (HPV16,18) & (Omrani et al., 2007) \\
\hline & Tehran (2002-2008) & 2011 & $(18-59)$ & 2 & $2(100)$ & PCR (GPs) & Reverse-line blot hybridization & (Khodakarami et al., 2012) \\
\hline & Isfahan (2007-2009) & 2011 & $52(29-73)$ & 29 & $27(93.1)$ & PCR (GPs) & - & (Allameh et al., 2011) \\
\hline & Isfahan (2006-2010) & 2011 & - & 12 & $12(100)$ & PCR (GPs) & Real-time & (Heidarpour et al., 2011) \\
\hline & Mazandaran (2009-2011) & 2013 & 52.6 & 12 & $8(66.7)$ & PCR & $\begin{array}{l}\text { HPVGenotype-Eph kit } \\
\text { (AmpliSens) }\end{array}$ & (Allameh et al., 2011) \\
\hline & Mazandaran (2008-2009) & 2013 & 26.19 & 11 & $2(18.2)$ & PCR & - & (Sharbatdaran et al., 2013) \\
\hline \multirow[t]{8}{*}{ LSIL } & Tehran (2005-2006) & 2006 & 35.3 & 12 & $7(58.3)$ & PCR (GPs) & TSP (HPV6,11,16,18,31,33) & (Ghaffari et al., 2006) \\
\hline & $\begin{array}{l}\text { "East Azarbaijan } \\
(2000-2006) "\end{array}$ & 2007 & $51.1(29-79)$ & 23 & $9(39.1)$ & PCR (GPs) & Type specific multiplex & (Esmaeili et al., 2008) \\
\hline & Ormia (1999-2005) & 2007 & $51.8(31-83)$ & 16 & $3(18.7)$ & PCR & TSP $(H P V 16,18)$ & (Omrani et al., 2007) \\
\hline & Tehran (2002-2008) & 2011 & $(18-59)$ & 3 & $0(0.0)$ & PCR (GPs) & Reverse-line blot hybridization & (Khodakarami et al., 2012) \\
\hline & Isfahan (2007-2009) & 2011 & $52(29-73)$ & 39 & $36(92.3)$ & PCR (GPs) & - & (Allameh et al., 2011) \\
\hline & Isfahan (2006-2010) & 2011 & - & 12 & $12(100)$ & PCR (GPs) & Real-time & (Heidarpour et al., 2011) \\
\hline & Mazandaran (2009-2011) & 2013 & 52.6 & 19 & $14(73.7)$ & PCR & $\begin{array}{l}\text { HPV Genotype-Eph kit } \\
\text { (AmpliSens) }\end{array}$ & (Allameh et al., 2011) \\
\hline & Mazandaran (2008-2009) & 2013 & 29.31 & 2 & $1(50.0)$ & PCR & - & (Sharbatdaran et al., 2013) \\
\hline \multirow[t]{6}{*}{ ASCUS } & Gilan & 2002 & - & 8 & $5(62.5)$ & PCR (GPs) & ISH & (Hamkar et al., 2004) \\
\hline & Golestan & 2002 & - & 6 & $4(66.7)$ & PCR (GPs) & ISH & (Hamkar et al., 2004) \\
\hline & Mazandaran & 2002 & & 14 & $9(64.3)$ & PCR (GPs) & ISH \& Sequencing & (Hamkar et al., 2002) \\
\hline & Tehran (2005-2006) & 2006 & 35.3 & 31 & $18(58.1)$ & PCR (GPs) & TSP (HPV6,11,16,18,31,33) & (Ghaffari et al., 2006) \\
\hline & Isfahan (2007-2009) & 2011 & $52(29-73)$ & 15 & $10(66.7)$ & PCR (GPs) & - & (Allameh et al., 2011) \\
\hline & Mazandaran (2008-2009) & 2013 & 29.31 & 17 & $0(0.0)$ & PCR & - & (Sharbatdaran et al., 2013) \\
\hline \multirow[t]{12}{*}{ Normal } & Gilan & 2002 & - & 34 & $3(8.8)$ & PCR (GPs) & ISH & (Hamkar et al., 2004) \\
\hline & Golestan & 2002 & - & 38 & $2(5.3)$ & PCR (GPs) & ISH & (Hamkar et al., 2004) \\
\hline & Mazandaran & 2002 & & 44 & $4(9.1)$ & PCR (GPs) & ISH \& Sequencing & (Hamkar et al., 2002) \\
\hline & Tehran (2005-2006) & 2006 & 33 & 77 & $10(13)$ & PCR (GPs) & TSP (HPV6,11,16,18,31,33) & (Ghaffari et al., 2006) \\
\hline & Tehran (2003-2005) & 2008 & $(15-55)$ & 597 & $31(5.2)$ & PCR (GPs) & Sequencing & (Jamali Zavarei et al., 2008) \\
\hline & Fars (July to Dec 2008) & 2010 & $35.2(20-72)$ & 402 & $22(5.5)$ & PCR & TSP ( HPV16,18) & (Safaei et al., 2010) \\
\hline & Bushehr (2008-2009) & 2010 & - & 200 & $11(5.5)$ & PCR (GPs) & Sequencing & (Zandi et al., 2010) \\
\hline & Golestan & 2011 & $37.54(15-75)$ & 226 & $41(18.1)$ & PCR (GPs) & TSP $(H P V 16,18)$ & (Moradi et al., 2011) \\
\hline & Tehran (2002-2008) & 2011 & $(18-59)$ & 791 & $52(6.6)$ & PCR (GPs) & Reverse-line blot hybridization & (Khodakarami et al., 2012) \\
\hline & Isfahan (2009-2010) & 2012 & $(18-60)$ & 180 & $46(25.5)$ & PCR (GPs) & TSP (HPV6,11,16,18) & (Allameh et al., 2013) \\
\hline & Bushehr (2009-2010) & 2012 & 35.96 & 799 & $5(0.62)$ & PCR & INNO-LiPA & (Eghbali et al., 2012) \\
\hline & Mazandaran (2008-2009) & 2013 & 26.19 & 60 & $0(0.0)$ & PCR & - & (Sharbatdaran et al., 2013) \\
\hline \multirow{6}{*}{$\begin{array}{l}\text { Head \& neck } \\
\text { Oral cavity \& } \\
\text { oropharyngeal }\end{array}$} & Sistan \& Balochestan & 2005 & $56.6(35-80)$ & 51 & $11(21.6)$ & PCR (MYs) d & TSP (HPV6,11,16,18,31,33) & (Sargolzaie et al., 2005) \\
\hline & Kerman (1995-2003) & 2006 & $51(27-74)$ & 15 & $9(60.0)$ & PCR (MYs) & TSP $(H P V 16,18)$ & (Zarei et al., 2007) \\
\hline & Tehran & 2010 & 44.37 & 24 & $15(62.5)$ & Nested-PCR (MYs & $(\mathrm{s}+\mathrm{GPs}) \quad$ EIA & (Haratian et al., 2010) \\
\hline & Tehran (2001-2008) & 2011 & $57.88(22-84)$ & 94 & $25(26.6)$ & PCR & HPV16,18 typing by kit & (Seraj et al., 2011) \\
\hline & East Azarbaijan & 2011 & $68.9(48-85)$ & 30 & $6(20.0)$ & PCR (MYs) & - & (Halimi \& Morshedi, 2011b) \\
\hline & East Azarbaijan & 2012 & $39.71(27-50)$ & 14 & $8(57.1)$ & $\begin{array}{c}\text { Nested-PCR } \\
\text { (MYs and GPs)", }\end{array}$ & Sequencing & (Asvadi Kermani et al., 2012) \\
\hline \multirow[t]{3}{*}{ Oral lesions } & Kerman (1995-2003) & 2006 & $40.5(4-67)$ & 45 & $7(15.5)$ & PCR (MYs) & TSP (HPV16,18) & (Zarei et al., 2007) \\
\hline & Isfahan & 2009 & $49.55(22-84)$ & 29 & $9(31.0)$ & PCR of HPV 18 & PCR of HPV 18 & (Razavi et al., 2009) \\
\hline & Khorasan Razavi & 2011 & - & 20 & $0(0.0)$ & PCR & TSP (HPV16,18,31,33) & (Saghravanian et al., 2011) \\
\hline \multicolumn{9}{|c|}{ Saliva or oral mucosa of healthy subjects } \\
\hline & Sistan \& Balochestan & 2005 & 30.7 & 28 & $1(3.6)$ & PCR (MYs) & TSP ( HPV6,11,16,18,31,33) & (Sargolzaie et al., 2005) \\
\hline & Isfahan & 2009 & $48.5(29-70)$ & 14 & $1(7.1)$ & PCR of HPV 18 & PCR of HPV 18 & (Razavi et al., 2009) \\
\hline & Tehran & 2009 & 64.4 & 20 & $5(25.0)$ & PCR (GPs) & TSP ( HPV6,11,16,18,31,33) & (SahebJamee et al., 2009) \\
\hline & Khorasan Razavi & 2011 & - & 18 & $0(0.0)$ & PCR & TSP (HPV16,18,31,33) & (Saghravanian et al., 2011) \\
\hline & East Azarbaijan & 2013 & $31.6(16-61)$ & 114 & $7(6.1) \mathrm{N}$ & Nested-PCR (MYs + & + GPs) Sequencing & (Seifi et al., 2013) \\
\hline
\end{tabular}

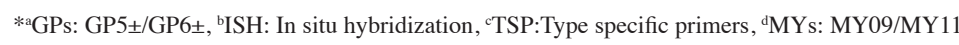


associated cancers, HPV-related non-malignant diseases and cancers may be associated with HPV in Iranian population.

\section{Materials and Methods}

A systematic review of the published studies up to November 2013 was carried out to assess the prevalence and HPV types in variety of cancers that are associated with HPV (anogenital cancers as well as head and neck cancers) or may be associated with HPV. Data were obtained by searches of PubMed, Current Contents, Scopus and national databases including IranMedex, SID, Magiran with the following search terms: "human papillomavirus (HPV)", "cancer/neoplasms", "epidemiology", "prevalence", and "Iran".

The following information were obtained from each included article: first author, year of publication, journal name, study period, sample size, age, gender, city, type of cancer, HPV detection methods, HPV prevalence, HPV genotyping methods and HPV types.

After exclusion of some studies due to duplication or irrelevant data, 61 studies were included in this study.

\section{Results}

Present systematic review was included 61 studies on variety of cancers that strongly or weekly associated with HPV. Tables 1 and 2 summarize the studies on HPV-related cancers and cancers may be associated with HPV in Iranian population, respectively. The prevalence of HPV16 and 18 types in different kind of cancers were shown in Figure 1.

\section{HPV associated-cancers}

Anogenital cancers. HPV prevalence data only were available for cervical cancer, but not for the other kind of anogenital cancers including vulva, vagina, penil and anal. Crude HPV prevalence was $77.5 \%, 66.9 \%, 65.1 \%$, $50.5 \%$ and $6.6 \%$ among ICC, HSIL, LSIL, ASCUS and normal cases in Iran (Table 3). HPV16 was the most prevalent HPV type for all five histological types, followed by HPV18, 6/11, 31 and 33 types. Also HPV45, 58, 59, 68 and 73 types were detected in a minority of subjects.

Table 2. List of Studies on HPV May be Associated-cancers and Corresponding Controls in Iranian Population

\begin{tabular}{|c|c|c|c|c|c|c|c|}
\hline \multirow[t]{2}{*}{ Cancer type } & \multirow{2}{*}{$\begin{array}{c}\text { "Province } \\
\text { (sampling time)" }\end{array}$} & \multirow[t]{2}{*}{ Year } & \multicolumn{2}{|c|}{ HPV positive } & \multirow{2}{*}{$\begin{array}{l}\text { "Method } \\
\text { (Primers)" }\end{array}$} & \multirow[t]{2}{*}{ Typing-method } & \multirow[t]{2}{*}{ References } \\
\hline & & & Cancer & Control & & & \\
\hline \multirow[t]{8}{*}{ ESCCa } & Golestan (1997-98) & 2002 & $42 / 85$ & - & PCR (GPs) ${ }^{\mathrm{b}}$ & Sequencing & (Moradi et al., 2002) \\
\hline & Tehran (1996-2001) & 2005 & $14 / 38$ & $5 / 38$ & PCR $(M Y s)^{c}$ & TSP d (HPV16,18) & (Farhadi et al., 2005) \\
\hline & Tehran & 2007 & $33 / 140$ & - & PCR (GPs) & Sequencing & (Far et al., 2007) \\
\hline & $\begin{array}{l}\text { "Mazandaran } \\
\text { (2001-2008)" }\end{array}$ & 2011 & $15 / 40$ & $5 / 40$ & AmpliSense PCR Kit & $\begin{array}{l}\text { "AmpliSense } \\
\text { FRT PCR Kit" }\end{array}$ & (Emadeian et al., 2011) \\
\hline & Fars (1982-2002) & 2012 & $0 / 92$ & $0 / 20$ & PCR & - & (Noori et al., 2012) \\
\hline & Tehran (1991-2005) & 2012 & $8 / 93$ & - & PCR (SPF10) & INNO-LiPA & (Abdirad et al., 2012) \\
\hline & Mazandaran (2004-2011) & 2012 & $49 / 177$ & - & Real-time PCR (MYs) & $\begin{array}{l}\text { “AmpliSense } \\
\text { FRT PCR Kit" }\end{array}$ & (Yahyapouretal.,2012) \\
\hline & Tehran & 2013 & $0 / 30$ & - & PCR (GPs) & - & (Haeri et al., 2013) \\
\hline \multirow[t]{3}{*}{ Lung cancer } & Mazandaran (1998-2004) & 2007 & $33 / 141$ & $8 / 92$ & $\begin{array}{l}\text { "Nested-PCR } \\
\text { (MY and GP)" }\end{array}$ & Sequencing & (Nadji et al., 2007) \\
\hline & - & 2004 & 18-Aug & - & $\begin{array}{c}\text { "Semi-nested PCR for } \\
\text { HPV-16 \& 18" }\end{array}$ & TSP (HPV16,18) & (Shafaghi et al., 2004) \\
\hline & $\begin{array}{l}\text { "East Azarbaijan } \\
\text { (2009-2011)" }\end{array}$ & 2011 & 30-Mar & - & PCR (MYs) & - & (Halimi \& Morshedi, \\
\hline \multirow[t]{2}{*}{ 2011) } & & & & & & & \\
\hline & $\begin{array}{c}\text { "East Azarbaijan } \\
\text { 2006-2009)" } \\
\text { (MY and GP)" }\end{array}$ & $\begin{array}{c}2013 \\
\text { Sequencing }\end{array}$ & $\begin{array}{c}9 / 50 \\
\text { (Jafari et al., } 2013\end{array}$ & 3) & "Nested-PCR & & \\
\hline \multirow[t]{4}{*}{ Prostate cancer } & Tehran & 2011 & $13 / 104$ & $8 / 104$ & $\begin{array}{c}\text { "Nested-PCR } \\
\text { (MYs and GPs)" }\end{array}$ & Sequencing & (Aghakhanietal.,2011) \\
\hline & Isfahan (2001-2006) & 2011 & 30-Mar & $1 / 90$ & $\mathrm{IHC} \mathrm{e}$ & - & (Mokhtari et al., 2011) \\
\hline & Gilan & 2012 & $3 / 68$ & $0 / 85$ & PCR (MYs) & - & (Salehi\&Hadavi,2012) \\
\hline & Tehran & 2013 & 29-May & $8 / 167$ & $\begin{array}{l}\text { "Nested-PCR } \\
\text { (MY and GP)" }\end{array}$ & - & (Ghasemianetal.,2013) \\
\hline \multirow{3}{*}{$\begin{array}{l}\text { Urinary tract- } \\
\text { cancers }\end{array}$} & Tehran (1999-2002) & 2005 & $21 / 59$ & $20-01$ & PCR & RFLP & (Barghi et al., 2005) \\
\hline & Fars (2003-2006) & 2012 & $7 / 49$ & $0 / 16$ & Nested-PCR & Sequencing & (Salehipouretal.,2012) \\
\hline & Tehran & 2008 & $51 / 147$ & $3 / 39$ & "PCR Kit (Sacace)" & $\begin{array}{l}\text { "Typing PCR Kit } \\
\text { (Sacace)" }\end{array}$ & (Eslami et al., 2008a) \\
\hline \multirow[t]{3}{*}{ Breast cancer } & Golestan & 2009 & $0 / 231$ & - & $\begin{array}{l}\text { "Nested-PCR } \\
\text { (MY and GP)" }\end{array}$ & - & (Moradi et al., 2009) \\
\hline & - & 2011 & $20 / 67$ & - & - & - & (Ghaffari et al., 2011) \\
\hline & Mazandaran (2002-2009) & 2012 & $16 / 79$ & $1 / 59$ & PCR (GPs, CP \& FAP) & Sequencing & (Sigaroodi et al., 2012) \\
\hline \multirow{3}{*}{$\begin{array}{l}\text { Skin cancer } \\
\text { 2007) }\end{array}$} & Mazandaran & 2007 & $35 / 136$ & $1 / 139 “ \mathrm{I}$ & 'Nested-PCR (MY and GP)' & )" Sequencing & (Shahmahmoudi et al., \\
\hline & Tehran & 2012 & $18 / 60$ & $15 / 60$ & PCR (MYs) & INNO-LiPA & (Shayanfar et al., 2013) \\
\hline & Isfahan & 2005 & $13 / 66$ & $2 / 66$ & - & - & (Mokhtari \& Bayat, \\
\hline
\end{tabular}

2005)

Conjunctiva SCC f

Tehran (2000-2006) 2011

$46 / 50$

0/50 “Nested-PCR (MY and GP)” TSP (HPV16,18) (Asadi-Amoli et al., 2011)

*aaSCC: Esophagus squamous cell carcinoma, ${ }^{\mathrm{b}} \mathrm{GPs}$ : GP5+/GP6+, ${ }^{\mathrm{c}} \mathrm{MYs}$ : MY09/MY11, ${ }^{\mathrm{d} T S P}$ :Type specific primers, ${ }^{\mathrm{e}} \mathrm{IHC}$ : Immunohistochemistry, ${ }^{\mathrm{f}} \mathrm{SCC}$ : squamous cell carcinoma 


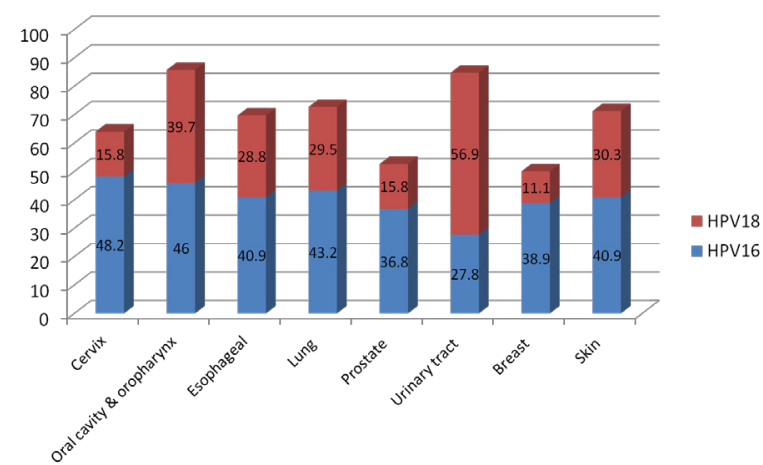

Figure 1. Prevalence of HPV16 and 18 Types in a Variety of Cancers

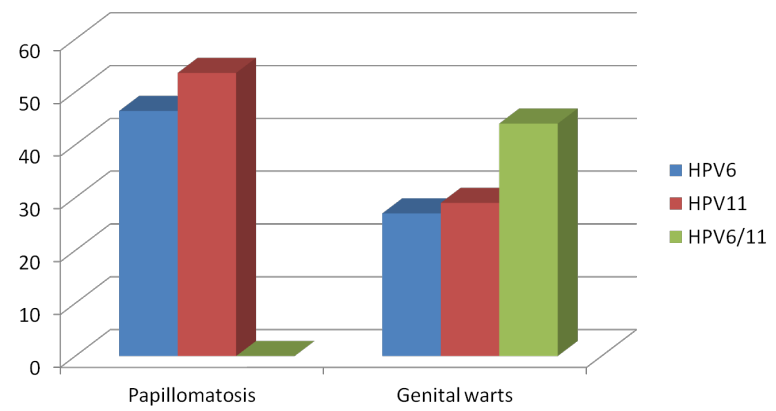

Figure 1. Prevalence of HPV 11, 16 and 18 Types in Non- Cancer Lesions

Head and neck cancers. The crude HPV prevalence $32.4 \%$ was estimated in patients with Oral cavity and oropharyngeal cancers. Also, HPV was detected in 17\% and $7.2 \%$ of oral lesions and Saliva and/or oral mucosa of healthy subjects, respectively (Table 3 ). The most common HPV types were HPV16 and 18, followed by 6,11 and 31 .

\section{Cancers may be associated with HPV}

Esophagus squamous cell carcinoma: The overall HPV prevalence in esophageal cancer and control groups was $23.1 \%$ and $10.2 \%$, respectively. According to HPV types, the most common type was HPV16 (40.9\%) in cases. The other high-risk types were HPV18, 31, 33, 45 and 52. In contrast, in control group the prominent type was HPV 18 (70\%) followed by HPV16 (30\%).

Lung cancer: HPV positivity in lung cancer and corresponding control groups estimated $22.2 \%$ and $8.7 \%$, respectively. The two most frequent types were HPV 16 and 18 in cases, followed by $6 / 11$ and 31, but HPV6/11 were prominent in control group.

Prostate cancer: The crude HPV prevalence was $10.4 \%$ versus $3.8 \%$ in prostate cancer cases and benign prostatic hyperplasia subjects, respectively. Regarding to HPV types, detection of HPV16 and 18 in cases were almost equal to controls.

Urinary tract cancers: Frequency of HPV estimated $30.9 \%$ and $5.3 \%$ in urinary tract cancer and control groups, respectively. The most frequent type was HPV18, followed by HPV 16 in case and control groups. However, in case group other types including HPV6, 31,33 and 52 detected in few samples.

Breast cancer: The overall HPV prevalence in breast cancer cases and control subjects was $14 \%$ and $1.1 \%$, respectively. The most prevalent HPV type was HPV16
Table 3.Overall HPV and Type-specific HPV prevalence in Variety of Cancers and Controls in Iranian Population

\begin{tabular}{lcccc}
\hline Cancer types & No. of cases & $\begin{array}{c}\text { HPV Posi- } \\
\text { tive n (\%) }\end{array}$ & HPV types \\
& & $\begin{array}{c}\text { High- } \\
\text { risk }\end{array}$ & $\begin{array}{c}\text { Interme- } \\
\text { diate or- }\end{array}$ & Unde- \\
& & ter- & Low-risk & mined
\end{tabular}

\begin{tabular}{|c|c|c|c|c|c|}
\hline \multicolumn{6}{|c|}{ HPV associated-cancers and controls } \\
\hline \multicolumn{6}{|c|}{ Cervical cancer } \\
\hline ICC & 862 & $668(77.5)$ & 618 & 27 & 23 \\
\hline HSIL & 148 & $99(66.9)^{\mathrm{a}}$ & 101 & 8 & 0 \\
\hline LSIL & 126 & $82(65.1)$ & 70 & 6 & 6 \\
\hline ASCUS & 91 & $46(50.5)$ & 32 & 9 & 5 \\
\hline Normal cervical cytology & 3448 & $227(6.6)$ & 162 & 30 & 35 \\
\hline \multicolumn{6}{|c|}{ Head \& neck cancers } \\
\hline $\begin{array}{l}\text { Oral cavity and- } \\
\text { oropharyngeal cancers }\end{array}$ & 228 & $74(32.4)$ & 63 & 4 & 7 \\
\hline Oral lesions & 94 & $16(17)$ & 11 & 5 & 0 \\
\hline $\begin{array}{l}\text { Saliva or oral mucosa- } \\
\text { of healthy subjects }\end{array}$ & 194 & $14(7.2)$ & 11 & 3 & 0 \\
\hline \multicolumn{6}{|c|}{ HPV weekly associated-cancers and controls } \\
\hline $\begin{array}{l}\text { Esophageal squamous- } \\
\text { cell carcinoma }\end{array}$ & 695 & $161(23.1)^{\mathrm{a}}$ & 118 & 25 & 35 \\
\hline Normal endoscopy tissue & 98 & $10(10.2)$ & 10 & 0 & 0 \\
\hline Lung cancer & 239 & $53(22.2)$ & 43 & 7 & 3 \\
\hline Controls & 92 & $8(8.7)$ & 3 & 5 & 0 \\
\hline Prostate cancer & 231 & $24(10.4)$ & 10 & 3 & 11 \\
\hline Benign prostate hyperplasia & 446 & $17(3.8)$ & 5 & 3 & 9 \\
\hline Urinary tract cancers & 255 & $79(30.9)^{\mathrm{a}}$ & 78 & 4 & 0 \\
\hline Benign lesions & 75 & $4(5.3)$ & 4 & 0 & 0 \\
\hline Breast cancer & 427 & $60(14)^{\mathrm{a}}$ & 36 & 26 & 1 \\
\hline Benign lesions & 88 & $1(1.1)$ & 0 & 1 & 0 \\
\hline Skin cancer $(\mathrm{SCC} \& \mathrm{BCC})^{\mathrm{b}}$ & 262 & $66(25.2)^{\mathrm{a}}$ & 48 & 12 & 17 \\
\hline Benign lesions & 265 & $18(6.8)$ & 1 & 0 & 17 \\
\hline $\begin{array}{l}\text { Conjunctiva squamous- } \\
\text { cell carcinoma }\end{array}$ & 50 & $46(92)$ & 0 & 0 & $46^{\mathrm{c}}$ \\
\hline Normal conjunctiva & 50 & $0(0.0)$ & 0 & 0 & 0 \\
\hline \multicolumn{6}{|c|}{ HPV-associated non-malignant diseases } \\
\hline $\begin{array}{l}\text { Recurrent respiratory- } \\
\text { papillomatosis }\end{array}$ & 29 & $28(96.5)$ & 0 & 28 & 0 \\
\hline Genital warts & 165 & $100(60.4)$ & 0 & 100 & 0 \\
\hline
\end{tabular}

*acoinfection cases reported; ${ }^{\mathrm{b}}$ Squamous cell carcinoma $(\mathrm{SCC})=163$, Basal cell carcinoma $(\mathrm{BCC})=99$ cases; ${ }^{c}$ types of all samples was not HPV16,18,31,33 , but the other types did not determine

in breast cancer patients, followed by HPV6, 11 and 18 . In few samples the other HPV types including 15, 23, 31, 33 and 124 detected. In control group, the only one HPV detected was HPV124.

Skin cancers: HPV positivity in non-melanoma skin cancers (squamous cell carcinoma [SCC] and basal cell carcinoma [BCC]) and control groups obtained $25.2 \%$ and $6.8 \%$, respectively. According to histological stratification, HPV detected in $22.7 \%$ and $29.3 \%$ of SCC and BCC cases, respectively. Regarding to HPV types in skin cancer patients, HPV16 and 18 were more prevalent. The other types detected were HPV6, 11, 56. In control group, HPV types did not determine.

Conjunctiva squamous cell carcinoma: HPV was detected in $92 \%$ of conjunctiva cancer, but not among control group. All samples were negative for HPV16, 18,31 and 33 . 


\section{HPV-related non-malignant diseases}

There are few reports about HPV prevalence and type distribution in genital warts (GW) (Nassiri et al., 2009; Jamshidi et al., 2012) and recurrent respiratory papillomatosis (RRP) (Izadi et al., 2012) in Iran. In these studies, HPV detected in $60.4 \%$ and $96.5 \%$ of GW and RRP cases, respectively. Nearly all HPV positive cases were infected with HPV6 and 11. In genital warts group, many subjects were coinfected with HPV6/11 (44\%).

\section{Discussion}

This systematic review obtained from 61 published studies estimated the prevalence of HPV infection and HPV types in HPV-associated cancers, cancers may be associated with HPV and HPV-related non-malignant diseases in Iranian population. Therefore, present study allowed us to make the inclusive estimates of HPV prevalence and HPV types in different kind of cancers in Iran.

In most studies on ICC in Iran, HPV prevalence was less than $100 \%$ prevalence that might be attributable to low sensitivity of techniques used to detect HPV DNA. The overall HPV prevalence of HSIL and LSIL were $66.9 \%$ and $65.1 \%$, respectively. HPV prevalence was diverse among HSIL and LSIL Iranian subjects that likely are result of small sample size and using different methods to detection of HPV. The six most common HPV types were HPV16, 18, 6/11, 31 and 33 in all groups. The most frequent HPV type was HPV16 followed by HPV18 in all five different histology. It is estimated that $70.1 \%$ of ICC are caused by HPV 16 or 18 worldwide (Castellsague et al., 2007).

In present study HPV detected in $44.4 \%$ of patients with head and neck cancers. The most common HPV types were HPV16 and 18. It is demonstrated that HPV infection is causally related to head and neck cancers (Kreimer et al., 2005; Strati et al., 2006; Gillison et al., 2012b; Jung et al., 2010). A strong association between HPV 16 and oropharyngeal cancer has been demonstrated in frequent case-control studies (Kreimer et al., 2005; Sudhoff et al., 2011). Moreover, a small fraction of head and neck cancers may be caused by further HPV types such as HPV 18, 31, 33, 35 (Gillison et al., 2012a).

In all HPV weekly associated-cancers investigated in this study HPV detected in a number of cancer cases and control subjects. However, the HPV was more prevalent in cases versus controls. HPV16 and 18 were most frequent HPV types in all cancers ranging from $50 \%$ to $84.7 \%$. These findings are consistent to some epidemiological studies that had been reported HPV detection in variety of cancers (Syrjanen, 2002a; 2002b; Iftner et al., 2003; Rezazadeh et al., 2009a; Tornesello et al., 2009; Li et al., 2011; Lin et al., 2011; Munoz et al., 2012; Simoes et al., 2012). However, detection of HPV DNA in these cancers by PCR alone is inadequate to verify causality. Therefore, to confirm the casually role of HPV in these kind of cancers, it is mandatory to investigate the biological activities of HPV such as E6/E7 expression or integration in these precancerous and cancerous lesions. Moreover, experimental models are needed to investigate the initiation and maintenance processes of tumorgenesis in these cancers. If the association of HPV with these cancers proves, it will be good news for prevention of these malignancies as current HPV vaccines will reduce dramatically the incidence of them.

In conclusion, pooled data of epidemiological studies in Iran suggest that HPV may play an important role in progression of cancers of the esophagus, skin, breast, lung, prostate and urinary tract. However, these findings should be verified by precise investigation of HPV transformational activity in these cancers. In another aspect, findings of present study imply that current HPV vaccines for cervical cancer may decline the burden of other cancers if they will really relate to HPV.

\section{References}

Abdirad A, Eram N, Behzadi AH, et al (2012). Human papillomavirus detected in esophageal squamous cell carcinoma in Iran. Eur J Intern Med, 23, 59-62.

Aghakhani A, Hamkar R, Parvin M, et al (2011). The role of human papillomavirus infection in prostate carcinoma. Scand J Infect Dis, 43, 64-9.

Allameh T, Moghim M, Farahbod F (2013). Reviewing the prevalence of human papillomavirus (HPV) in married women aged 18-60 years with normal pap smear and referring to gynecology clinics in hospitals affiliated to isfahan university of medical sciences, Iran J Isfahan Medical School, 29, 2048-54.

Allameh T, Moghim S, sadi-Zeidabadi M (2011). A survey on the prevalence of high-risk subtypes of human papilloma virus among women with cervical neoplasia in Isfahan university of medical science. Arch Gynecol Obstet, 284, 1509-13.

Asadi-Amoli F, Heidari AB, Jahanzad I, Jabbarvand M (2011). Detection of human papillomavirus in squamous cell carcinoma of conjunctiva by nested PCR: a case control study in Iran. Acta Medica Iranica, 49, 707-14.

Asvadi Kermani I, Seifi S, Dolatkhah R, et al (2012). Human papilloma virus in head and neck squamous cell cancer. Iran J Cancer Prev, 5, 21-6.

Barghi MR, Hajimohammadmehdiarbab A, Moghaddam SM, KAZEMI B (2005). Correlation between human papillomavirus infection and bladder transitional cell carcinoma. BMC Infect Dis, 5, 102.

Bouvard V, Baan R, Straif K, et al (2009). A review of human carcinogens-Part B: biological agents. Lancet Oncol, 10, 321-2.

Burnett-Hartman AN, Newcomb PA, Potter JD (2008). Infectious agents and colorectal cancer: a review of Helicobacter pylori, Streptococcus bovis, JC virus, and human papillomavirus. Cancer Epidemiol Biomarkers Prev, 17, 2970-9.

Castellsague X, de Sanjose S, Aguado T, et al (2007). HPV and cervical cancer in the world 2007 report. Vaccine, 25, C1-230.

Chelimo C, Wouldes TA, Cameron LD, Elwood JM (2013). Risk factors for and prevention of human papillomaviruses (HPV), genital warts and cervical cancer. J Infect, 66, 207-17.

Cogliano V, Baan R, Straif K, et al (2005). Carcinogenicity of human papillomaviruses. Lancet Oncol, 6, 204.

Doorbar J, Quint W, Banks L, et al (2012). The biology and life-cycle of human papillomaviruses. Vaccine, 30, 55-70.

Eghbali SS, Amirinejad R, Obeidi N, et al (2012). Oncogenic human papillomavirus genital infection in southern Iranian women: population-based study versus clinic-based data. 
Virol J, 9, 194.

Emadeian O, Naghshvar F, Rafiei A, et al (2011). Corroletion of Human Papillomavirus Infection with Esophageal Squamous Cell Carcinoma. J Babol University of Med Sciences, 13, 54-59.

Eslami G, Golshani M, Rakhshon M, (2008a). The study on relation of human papillomavirus with bladder transitional cell carcinoma. Cancer Therapy, 6, 355-60.

Eslami G, Golshani M, RAKHSHAN M, et al (2008b). PCR detection and high risk typing of human papillomavirus DNA in cervical cancer in Iranian women. Cancer Therapy, 6, 361-6.

Esmaeili M, Bonyadi M, Dastranj A, et al (2008). HPV typing in women with cervical precancerous and cancerous lesions in northwestern Iran. Gynecol Obstet Invest, 66, 68-72.

Far AE, Aghakhani A, Hamkar R, et al (2007). Frequency of human papillomavirus infection in oesophageal squamous cell carcinoma in Iranian patients. Scand J Infect Dis, 39, $58-62$.

Farhadi M, Tahmasebi Z, Merat S, et al (2005). Human papillomavirus in squamous cell carcinoma of esophagus in a high-risk population. World J Gastroenterol, 11, 1200-3.

Farjadian S, Asadi E, Doroudchi M, et al (2003). High risk HPV types in southern Iranian patients with cervical cancer. Pathol Oncol Res, 9, 121-5.

Ghaffari SR, Sabokbar T, Meshkat Z, et al (2011). Tracing human papilloma virus in breast tumors of Iranian breast cancer patients. Breast J, 17, 218-9.

Ghaffari SR, Sabokbar T, Mollahajian H, et al (2006). Prevalence of human papillomavirus genotypes in women with normal and abnormal cervical cytology in Iran. Asian Pac J Cancer Prev, 7, 529-32.

Ghasemian E, Monavari SH, Irajian GR, et al (2013). Evaluation of human papillomavirus infections in prostatic disease: a cross-sectional study in Iran. Asian Pac J Cancer Prev, 14, 3305-8.

Gillison ML, Alemany L, Snijders PJ, et al (2012). Human papillomavirus and diseases of the upper airway: head and neck cancer and respiratory papillomatosis. Vaccine, 30, 34-54.

Haeri H, Mardany O, sadi-Amoli F, Shahsiah R (2013). Human papilloma virus and esophageal squamous cell carcinom. Acta Med Iran, 51, 242-5.

Haghshenas M, Golini-Moghaddam T, Rafiei A, Emadeian O, Shykhpour A, Ashrafi GH (2013). Prevalence and type distribution of high-risk human papillomavirus in patients with cervical cancer: a population-based study. Infect Agent Cancer, 8, 20.

Halimi M, Morshedi AS (2011a). Human papillomavirus infection in lung $v s$ oral squamous cell carcinomas: a polymerase chain reaction study. Pak J Biol Sci, 14, 641-6.

Hamkar R, Mokhtari-Azad T, Mahmoodi M, et al (2004). Prevalence of various types of HPV among cervical cancer and normal biopsy in North of Iran. Iranian J Infect Diseases, 8, 9-15.

Hamkar R, Azad TM, Mahmoodi M, et al (2002). Prevalence of human papillomavirus in Mazandaran Province, Islamic Republic of Iran. East Mediterr Health J, 8, 805-11.

Haratian K, Mohseni Meybodi A, Zari Moradi S, Vosough P (2010). Detection of high risk human papillomavirus dna sequences in head and neck squamous cell carcinoma in iranian fanconi anemia patients. Yakhteh Med J, 12, 43-50.

Heidarpour M, Salehi R, Kamali Z, yaraghi H (2011). The frequency of high risk sub-types of human papillomavirus in the samples with varying degrees of cervical neoplasia. J Isfahan Med School, 28.

IARC. Section of Cancer Information. 2008. Scientific
Publications, Lyonn. Ref Type: Report

Iftner A, Klug SJ, Garbe C, et al (2003). The prevalence of human papillomavirus genotypes in nonmelanoma skin cancers of nonimmunosuppressed individuals identifies high-risk genital types as possible risk factors. Cancer Res, 63, 7515-9.

Izadi F, Hamkar R, Ghanbari H, Abdolmotallebi F, Jahandideh $H$ (2012). The role of Human papilloma virus (HPV) genotyping in recurrent respiratory papillomatosis in Rasoul Akram Hospital. Med J Islam Repub Iran, 26, 90-3.

Jafari H, Gharemohammadlou R, Fakhrjou A, et al (2013). Genotyping of human papillomavirus and TP53 mutaions at exons 5 to 7 in lung cancer patients from Iran. Bioimpacts, 3, 135-40.

Jamali Zavarei M, Hamkar R, Ghobadi Dana V, et al (2008). Prevalence of HPV infection and its association with cytological abnormalities of pap smears in Tehran. Iranian J Pub Health, 37, 101-6.

Jamshidi M, Shekari M, Nejatizadeh AA, et al (2012). The impact of human papillomavirus (HPV) types 6,11 in women with genital warts. Arch Gynecol Obstet, 286, 1261-7.

Jemal A, Bray F, Center MM, et al (2011). Global cancer statistics. CA Cancer J Clin, 61, 69-90.

Jung AC, Briolat J, Millon R, et al (2010). Biological and clinical relevance of transcriptionally active human papillomavirus (HPV) infection in oropharynx squamous cell carcinoma. Int J Cancer, 126, 1882-94.

Khodakarami N, Clifford GM, Yavari P, et al (2012). Human papillomavirus infection in women with and without cervical cancer in Tehran. Iran. Int J Cancer, 131, 156-61.

Kreimer AR, Clifford GM, Boyle P, Franceschi S (2005). Human papillomavirus types in head and neck squamous cell carcinomas worldwide: a systematic review. Cancer Epidemiol Biomarkers Prev, 14, 467-75.

Li N, Yang L, Zhang Y, et al (2011). Human papillomavirus infection and bladder cancer risk: a meta-analysis. J Infect Dis, 204, 217-23.

Lin Y, Mao Q, Zheng X, et al (2011). Human papillomavirus 16 or 18 infection and prostate cancer risk: a meta-analysis. Ir J Med Sci, 180, 497-503.

Lorenzon L, Ferri M, Pilozzi E, et al (2011). Human papillomavirus and colorectal cancer: evidences and pitfalls of published literature. Int J Colorectal Dis, 26, 135-42.

Mahmoodi MM, Hamkar R, Akhavan-Tafti M, et al (2007). HPV genotyping in cervical cancer in Yazd province. Iranian $J$ Infect Diseases, 12, 19-24.

Maleknejad P, Rakhshan M, Kazemi B, Farokh F, Shahsavan S (2006). Detection of human papilomavirus types 16 and 18 in pathologic samples from patients with cervical cancer by pcr and rflp methods. DARU, 14, 78-81.

Mokhtari M, BayatZ (2005). Detection of human papillomavirus in cutaneous squamous cell carcinoma using polymerase chain reaction. J Hamedan Med Sciences, 12, 5-9.

Mokhtari M, Taghizadeh F, Rouzbahani E, Narimani T (2011). Comparison of Relative Frequency of Human Papillomatous Virus by Using of Immiunohistochemistry Method between Patients with Prostatic Adenocarcinoma or Benign Prostatic Hyperplasia. J Isfahan Med School, 29, 80-5.

Moradi A, de Villiers EM, Mokhtari-Azad T, et al (2002). Detection of human papillomavirus DNA by PCR in esophageal squamous cell carcinoma from turkmen sahra, North-East of Iran. Iranian Biomed J, 6, 19-23.

Moradi A, Mobasheri E, Tabaraie A, et al (2009). Molecular epidemiology of HPV in breast cancer in golestan province. $J$ Laboratory Sciences, 3, 9-14.

Moradi A, Bakhshandeh Nosrat S, Besharat S (2011). Molecular epidemiology of high-risk types of human papillomaviruses $(16,18)$ in pap-smear, the North East of Iran. Iran J Cancer 
Prev, 3, 135-40.

Mortazavi S, Zali M, Raoufi M, et al (2002). The prevalence of human papillomavirus in cervical cancer in Iran. Asian Pac J Cancer Prev, 3, 69-72.

Moscicki AB, Schiffman M, Burchell A, et al (2012). Updating the natural history of human papillomavirus and anogenital cancers. Vaccine, $\mathbf{3}, 24-33$.

Munoz JP, Gonzalez C, Parra B, et al (2012). Functional interaction between human papillomavirus type $16 \mathrm{E} 6$ and E7 oncoproteins and cigarette smoke components in lung epithelial cells. PLoS One, 7, 38178 .

Munoz N, Bosch FX, de SS, et al (2003). Epidemiologic classification of human papillomavirus types associated with cervical cancer. $N$ Engl J Med, 348, 518-27.

Munoz N, Castellsague X, de Gonzalez AB, Gissmann L (2006). Chapter 1: HPV in the etiology of human cancer. Vaccine, 24, 3-1-310.

Nadji SA, Mahmoodi M, Ziaee AA, et al (2007). An increased lung cancer risk associated with codon 72 polymorphism in the TP53 gene and human papillomavirus infection in Mazandaran province, Iran. Lung Cancer, 56, 145-51.

Nassiri S, Sarlak M, Bidari Zereh Posh F, et al (2009). Polymerase chain reaction study of anogenital condylomas for high risk HPV types. Iranian J Dermatology, 12, 52-5.

Noori S, Monabati A, Ghaderi A (2012). The Prevalence of human papilloma virus in esophageal squamous cell carcinoma. Iran J Med Sci, 37, 126-33.

Omrani M, Saleh S, Lotfinejad S, et al (2007). Prevalence of HPV16 and 18 in cervical cancer by PCR in Western Azarbaijan. Urmia Med J, 18, 414-21.

Razavi SM, Ghalayan P, Salehi MR, et al (2009). Human papilloma virus as a possible factor in the pathogenesis of oral lichen planus. Dent Res J Isfahan, 6, 82-6.

Rezazadeh A, Laber DA, Ghim SJ, Jenson AB, Kloecker G (2009a). The role of human papilloma virus in lung cancer: a review of the evidence. Am J Med Sci, 338, 64-7.

Rodriguez AC, Schiffman M, Herrero R, et al (2010). Longitudinal study of human papillomavirus persistence and cervical intraepithelial neoplasia grade 2/3: critical role of duration of infection. $J$ Natl Cancer Inst, 102, 315-24.

Rosa MI, Silva GD, de Azedo Simoes PW, et al (2013). The prevalence of human papillomavirus in ovarian cancer: a systematic review. Int J Gynecol Cancer, 23, 437-41.

Safaei A, Khanlari M, Momtahen M, et al (2010). Prevalence of high-risk human papillomavirus types 16 and 18 in healthy women with cytologically negative pap smear in Iran. Indian J Pathol Microbiol, 53, 681-5.

Saghravanian N, Ghazvini K, Babakoohi S, Firooz A, Mohtasham $\mathrm{N}$ (2011). Low prevalence of high risk genotypes of human papilloma virus in normal oral mucosa, oral leukoplakia and verrucous carcinoma. Acta Odontol Scand, 69, 406-9.

SahebJamee M, Boorghani M, Ghaffari S, AtarbashiMoghadam F, Keyhani A (2009). Human papillomavirus in saliva of patients with oral squamous cell carcinoma. J Oral Med Pathology, 14, 525-8.

Salehi Z, Hadavi M (2012). Analysis of the codon 72 polymorphism of TP53 and human papillomavirus infection in Iranian patients with prostate cancer. J Med Virol, 84, 1423-7.

Salehipour M, Khezri A, Behzad-Behbahani A, et al (2012). Role of viruses in renal cell carcinoma. Saudi J Kidney Dis Transpl, 23, 53-7.

Sargolzaie S, Keikhaie M, Moradi A, Ghanbari M, Najmabadi $\mathrm{H}$ (2005). Human papillomavirus genotypes among patients with oral squamous cell carcinoma. J Dental School, Shahid Beheshti University Med Sci, 23, 438-48.

Seifi S, Asvadi K, I, Dolatkhah R, et al (2013). Prevalence of oral human papilloma virus in healthy individuals in East azerbaijan province of iran. Iran J Public Health, 42, 79-85.

Seraj JM, Yazdani N, Ashtiani ZO, et al (2011). TP53 gene expression in HPV-positive oral tongue SCC and its correlation with nodal metastasis. Pathol Res Pract, 207, 758-61.

Shafaghi B, Sabeti S, Mohammadi F, et al (2004). Detection of Human Papillomavirus in Squamous Cell Carcinoma of the Lung by Semi-nested PCR. Tanaffos, 3, 15-21.

Shahmahmoudi S, Mahmoodi M, Azad TM, et al (2007). Prevalence of mucosal types of human papillomavirus in skin lesions in north part of Iran. Cancer Lett, 247, 72-6.

Shahsiah R, Khademalhosseini M, Mehrdad N, Ramezani F, Nadji SA (2011). Human papillomavirus genotypes in Iranian patients with cervical cancer. Pathol Res Pract, 207, 754-7.

Sharbatdaran M, Siadati S, Zeinalzadeh M, et al (2013). The frequency of HPV 16 and 18 in cervical discharge by PCR in women with abnormal pap smear or biopsy. Iranian $J$ Pathology, 8, 17-20.

Shayanfar N, Hosseini N, Panahi M, et al (2013). Detection of mucosal type human papillomavirus in cutaneous squamous cell carcinoma in Iran. Pathol Res Pract, 209, 90-4.

Sigaroodi A, Nadji SA, Naghshvar F, et al (2012). Human papillomavirus is associated with breast cancer in the north part of Iran. Scientific World J, 2012, 837191.

Simoes PW, Medeiros LR, Simoes Pires PD, et al (2012). Prevalence of human papillomavirus in breast cancer: a systematic review. Int J Gynecol Cancer, 22, 343-7.

Strati K, Pitot HC, Lambert PF (2006). Identification of biomarkers that distinguish human papillomavirus (HPV)positive versus HPV-negative head and neck cancers in a mouse model. Proc Natl Acad Sci U S A, 103, 14152-7.

Sudhoff HH, Schwarze HP, Winder D, et al (2011). Evidence for a causal association for HPV in head and neck cancers. Eur Arch Otorhinolaryngol, 268, 1541-7.

Syrjanen KJ (2002b). HPV infections and oesophageal cancer. J Clin Pathol, 55, 721-8.

Syrjanen KJ (2002a). HPV infections and lung cancer. J Clin Pathol, 55, 885-91.

Tornesello ML, Monaco R, Nappi O, Buonaguro L, Buonaguro FM (2009). Detection of mucosal and cutaneous human papillomaviruses in oesophagitis, squamous cell carcinoma and adenocarcinoma of the oesophagus. J Clin Virol, 45, 28-33.

Yahyapour Y, Shamsi-Shahrabadi M, Mahmoudi M, et al (2012). High-risk and low-risk human papillomavirus in esophageal squamous cell carcinoma at mazandaran, Northern Iran. Pathol Oncol Res, 19, 385-91.

Yarandi F, Izadi Mood N, Eftekhar Z, Niakan R, Tajziachi S (2007). HPV infection among patients with high grade cervical intraepithelial neoplasia and squamous cell carcinoma of cervix. Tehran University Med J, 65, 5-11.

Zandi K, Eghbali SS, Hamkar R, et al (2010). Prevalence of various human papillomavirus (HPV) genotypes among women who subjected to routine Pap smear test in Bushehr city (south west of Iran) 2008-2009. Virol J, 7, 65 .

Zarei MR, Moradie A, Hamkar R, et al (2007). Detection of human papillomavirus dna sequences in oral lesions using polymerase chain reaction. Acta Med Iranica, 45, 177-82. 